\section{Indecent exposures}

June Goodfield

Marie Curie: A Life. By Susan Quinn. Simon and Schuster: 1995. Pp. 509. \$30.

WHEN I was a schoolgirl during the Second World War, the only available role model for an aspiring woman scientist was Marie Curie. Judging from the citations in dictionaries and encyclopaedias of scientists, even as late as the 1970 s, it would indeed have seemed that she was the only woman scientist. Awe-inspiring, brave, poor, she had a hard life. An emigrée from her native Poland which she adored, she devoted her efforts to physics and mathematics and to her colleague and husband, Pierre. If anything, her devotion and single-mindedness became more intense after the tragedy of his death. She acquired two Nobel prizes from Sweden and a few critical grams of radium from admirers in the United States. She continued to pay a high price for her selflessness and single-minded dedication, for even her final illness and death were provoked by exposure to radium, the new element she had discovered.

Our only source of popular reading about her was the biography by her daughter, Eve, published in 1937, three years after Marie died. The speed with which it was written was astonishing and quite deliberate. As Eve Curie Labouisse confessed to Susan Quinn 51 years later, she wrote quickly because she was "afraid that someone else would do it first and not get it right". This was not the first time - nor will it be the last - that a biography of a

Le Petit Journal marks Marie Curie's visit to the United States in 1921.

famous person has been assembled in a great hurry by relatives or devoted friends in order 'to get it right'. Sometimes they even do it themselves, as Margaret Mead once told me she had done with her autobiography, Blackberry Winter. Moreover, as Quinn points out, the portrait of Marie Curie that came down to us was not only a tremendous idealization but also served as a defence by Eve Curie of her mother.

Such a defence was necessary because Marie Curie's affair with a fellow scientist, Paul Langevin - married and the father of four - led to her public exposure and dreadful vilification. Although dismissed by Eve Curie in a few paragraphs, this episode was not only a major trauma for Marie Curie but also reflected many things: the passionate woman whose objectivity could collapse - as most people's can - when the heart and emotions are closely involved; the crucial

attitudes of fellow scientists; and the social milieu in which she worked and lived.

Fifty years ago, myth and idealization, nobility and dedicated objectivity were the hallmarks of science. The image of the noble scientist - mostly men of course, plus Marie Curie - was not only endorsed by scientists themselves but also

\section{IMAGE UNAVAILABLE FOR COPYRIGHT REASONS}

often positively promoted. This noble edifice began to crumble almost in direct proportion to the speed with which the enterprise of science, and the number of its practitioners, began to increase. In the United States this was due to the establishment of the National Science Foundation and the National Institutes of Health and to the administration of President John F. Kennedy. The ultimate financial commitment was a pork barrel of such wealth that Jerome Wiesner was once moved to observe that he had never seen one of such dimensions, the real difference this time being that "the pigs were running the show". As the money available increased, so did the competition for it. As the competition intensified, so the ethics, the image and indeed the actions of some of those very 'noble' - as well as Nobel - scientists were eroded. And with the publication of The Double Helix, that deliciously indiscreet, sometimes very unfair but frank account of the discovery of the structure of DNA, Jim Watson gave a new dimension to the image of the scientist, with the magisterial imprimatur of one who had gained the most coveted success of all.

But if the ambience and image of science have changed, so too have other elements of the profession. Science now operates not only with many more women scientists than ever before, but also in an atmosphere that is strongly feminist - at least in the United States. And this provides the main motive for Quinn's biography. For as she writes: "my reasons for undertaking a biography of Marie Curie were as much of our time as Eve Curie's were of hers. . I I have looked for evidence that Marie $\sum$ Curie was not just a singular, exceptional woman (though she was indeed that) but also a woman who experienced the same difficulties as other women with strong opinions and ambitions."

Then, as now, there were many barriers to women's advancement in the profession. Then, as now, there were defeats and humiliations. In Marie Curie's case these came thick and fast at the hands of the French Academy of Sciences, the bourgeoisie and an "outrageous right wing press".

Quinn has produced a magisterial piece of work. Admittedly she has had access to sources not available until 1990 - notably Marie Curie's own journal. She has also delved deeply into family documents and into the archives in Warsaw, Paris and Sweden. The result is wonderful in its depth and detail, so much so that it will be years, if ever, before this account is displaced. Only new documents and new evidence could do that. Even then the book will probably never be superseded, only complemented.

Not only is this a biography that tells you everything that you need to know; it also succeeds, quite brilliantly, in a conceptually new way. By seeking to understand Marie Curie in terms of attitudes and questions relevant and prevalent at the end of the twentieth century, the author has gained a profound understanding of a woman scientist at the turn of the nineteenth century. This goes to show that in biography, just as much as in science, asking the right question is the beginning of wisdom. The balance too is right, beautifully judged between the science, the personality and Marie Curie's own belief that the most important part of her work was not the "much touted cure for cancer" but her "critical insight that radioactivity was an 'atomic property' of her newly discovered elements", the most 
important precursor to our modern understanding of atomic structure.

She strove throughout, and especially at the end, to keep a firm distinction between her personal and scientific life. But in this she failed, and a woman of greater understanding of the world would have realized that she was bound to fail.

She was awarded the Nobel prize for chemistry at the height of the open scandal over her affair with Langevin. A member of the Swedish Academy wrote to her indicating that she would not be welcome in Sweden and should refuse the prize until she had cleared her name. But, she replied, the prize was given for her discovery of polonium and radium, and nothing else. Was she right to insist - is any scientist right to insist - that there is "no connection between scientific work and private life"? Given the facts, and that she had written an incredibly indiscreet letter to her lover, with detailed recommendations as to how he could withhold sexual favours from his wife and thus make a break inevitable, there was probably no way that Marie Curie could be treated fairly by contemporary French society.

There is something very Janus-faced about the situation and, for an English reviewer, the furore and scandal that surrounded Marie Curie's affair in France is very hard to understand. For I am writing at a time when the president of France not only has an illegitimate daughter but is also applauded for his paternal devotion. This contrasts sharply with the speed with which a number of English politicians have resigned for extramarital affairs. Some have an illegitimate daughter as well, in one case two of them. As Quinn points out, in France certainly, bourgeois men could keep - and still can keep - a mistress so long as she stayed in the background, as did President François Mitterrand's. That enforcer of male privilege, the Napoleonic Code, was indulgent towards the husband. But Marie Curie was in no way anonymous; she could not fade into the background. She had a career, an independent income and ambitions, and was therefore completely vulnerable to public exposure. Her letters to her lover were stolen and published, letters fuelled by passion as fiery as the passion that, as Einstein pointed out, she demonstrated at scientific conferences.

Marie Curie's impotence in the face of the 'outrageous press' was total, as apparently is that of adulterous British politicians and all the rest. A touch of farce attended the affair when Langevin challenged Gustav Téry to a duel for insulting him in an article that accompanied the publication of the letters. Neither of them ever intended to fire the pistols, nor did they, but the duel was the talk of Paris and of Sweden too. It was shortly after this event that Marie Curie was recommended not to go to
Stockholm to receive the Nobel prize.

The episode affected her profoundly, of course, both personally and scientifically. It ruined her chances both of becoming a member of the French Academy of Sciences and of starting a new life with her lover. He was reconciled with his wife and took another mistress (an anonymous secretary) while Marie Curie was left to go on alone.

Whether about this scandal, or the details of her scientific discoveries, or her theories or her childhood, the material in this volume is impeccably researched and splendidly presented. This is not a book that one devours at a sitting as one did The Double Helix. It is far too profound and thought-provoking for that. Yet I also found it, and its subject, devoid of humour, as is Eve Curie's biography. True, there are lighter touches. As is usual with all good discoveries, quacks and opportunists raced to exploit them, trading on "the assumption that water's radioactivity had health giving powers and the Curies' good name". This lasted for a long time. I remember, again from my earlier years, drinking mineral water in France and seeing the label on the bottle list the quantities of magnesium, zinc and all the other goodies therein, and the radioactivity too. How quickly radioactivity disappeared from the list. So it is not surprising that there was a "Curie hair tonic" that was claimed to stop the loss of hair as well as restoring its colour and a "creme activa" that held out the promise of eternal youth with the statement that "Madame Curie. .. promises miracles".

All this was in deplorably bad taste of course. But the puzzle of Marie Curie persists. While she may have had her lighter moments, irreverent humour was never one of her strong characteristics; and perhaps it doesn't matter for scientists, other than that those without a sense of humour will have a hard time. If, on looking back, I realize I didn't have what it takes to be a scientific nun, it's quite clear from reading this book that Madame Curie didn't have it either. As a role model, the injection of Eve Curie's book provoked an immunity to dedicated laboratory work in me, although it had the opposite effect on my admirable sister.

So how, in 1995, would the Madame Curie portrayed in this biography shape up as a role model for today's aspiring women scientists? Although I don't really know, I suspect the young women of today will find more inspiration in the deliciously eccentric and formidable Barbara McClintock, who brilliantly and comprehensively gave those Young Turks of molecular biology their come-uppance. For we are all creatures of our times.

June Goodfield is at International Health and Biomedicine, The Manor House, Alfriston, East Sussex BN26 5SY, UK.

\section{My families and other animals}

\author{
W. C. McGrew
}

Reflections of Eden: My Life with the Orangutans of Borneo. By Biruté M. F. Galdikas. Little, Brown/Gollancz: 1995. Pp. 408. \$24.95, £16.99.

Now comes the long-awaited volume to complete primatology's most famous 'trilogy': Biruté Galdikas's account of her long-term field study of the orangutans of Kalimantan in Indonesia. She joins Jane Goodall (In the Shadow of Man, 1971; Through a Window, 1990) and the late Dian Fossey (Gorillas in the Mist, 1983) in

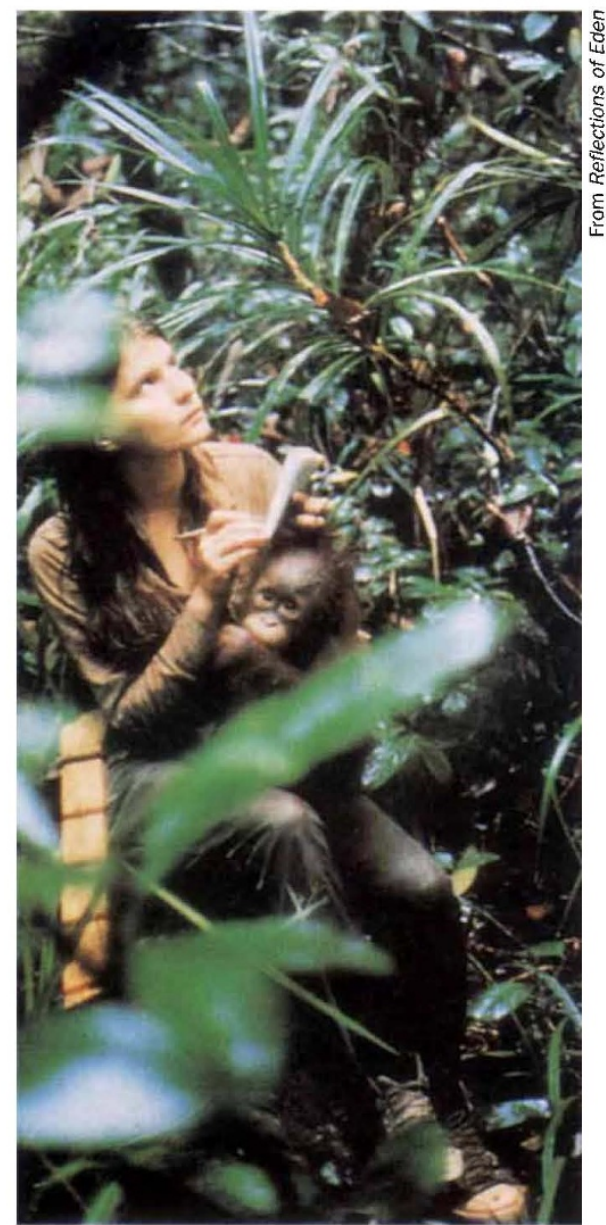

Galdikas: self-reflection of reflected self?

giving a personal report of behavioural research on great apes in nature. Goodall has studied the eastern chimpanzees of the Gombe National Park in Tanzania since 1960; Fossey looked at the mountain gorillas of the Virunga volcanoes in Rwanda from 1967 until her death in 1985; and Galdikas has focused on the Bornean orangutans of Tanjung Puting National Park since 1971.

What makes the project part of a trilogy is the common source: the AngloKenyan palaeoanthropologist Louis 